From the Division of Hepatology and Gene Therapy and Departments of Radiology, Pathology, Gastroenterology, Pharmacology, Hematology, Clínica Universitaria/ School of Medicine, Foundation for Applied Medical Research, University of Navarra, Pamplona, Spain.

Submitted August 24, 2004; accepted October 27, 2004.

Supported by grants from Ministerio de Ciencia y Tecnologia (SAF 02/ 0373), Fondo de Investigaciones Sanitarias (PI031253), Redes

Temáticas de Investigación Cooperativa (C03/10 and C03/02),

Departamento de Salud y Departamento de Educación del Gobierno de Navarra and "UTE-project CIMA".

Terms in blue are defined in the glossary, found at the end of this issue and online at www.jco.org.

Authors' disclosures of potential conflicts of interest are found at the end of this article

Address reprint requests to Guillermo Mazzolini MD, PhD, Clínica Universitaria/ School of Medicine, University of Navarra, c/lrunlarrea, s/n, 31008 Pamplona, Spain; e-mail: gmazzolini@unav.es.

(c) 2005 by American Society of Clinical Oncology

0732-183X/05/2305-999/\$20.00

DOI: $10.1200 / J C O .2005 .00 .463$

\title{
Intratumoral Injection of Dendritic Cells Engineered to Secrete Interleukin-12 by Recombinant Adenovirus in Patients With Metastatic Gastrointestinal Carcinomas
}

Guillermo Mazzolini, Carlos Alfaro, Bruno Sangro, Esperanza Feijoó, Juan Ruiz, Alberto Benito, Iñigo Tirapu, Ainhoa Arina, Josu Sola, Maite Herraiz, Felipe Lucena, Cristina Olagüe, José Subtil, Jorge Quiroga, Ignacio Herrero, Belén Sádaba, Maurizio Bendandi, Cheng Qian, Jesús Prieto, and Ignacio Melero

\section{$\begin{array}{llllllll}\text { A } & \text { B } & \text { S } & \text { T } & R & \text { A } & \text { C } & \text { T }\end{array}$}

\section{Purpose}

To evaluate the feasibility and safety of intratumoral injection of autologous dendritic cells (DCs) transfected with an adenovirus encoding interleukin-12 genes (AFIL-12) for patients with metastatic gastrointestinal carcinomas. Secondarily, we have evaluated biologic effects and antitumoral activity.

\section{Patients and Methods}

Seventeen patients with metastatic pancreatic ( $n=3$ ), colorectal ( $n=5)$, or primary liver ( $n=9$ ) malignancies entered the study. DCs were generated from CD14+ monocytes from leukapheresis, cultured and transfected with AFIL-12 before administration. Doses from $10 \times 10^{6}$ to $50 \times 10^{6}$ cells were escalated in three cohorts of patients. Patients received up to three doses at 21-day intervals.

\section{Results}

Fifteen (88\%) and 11 of 17 (65\%) patients were assessable for toxicity and response, respectively. Intratumoral DC injections were mainly guided by ultrasound. Treatment was well tolerated. The most common side effects were lymphopenia, fever, and malaise. Interferon gamma and interleukin-6 serum concentrations were increased in 15 patients after each treatment, as well as peripheral blood natural killer activity in five patients. DC transfected with AFIL-12 stimulated a potent antibody response against adenoviral capsides. DC treatment induced a marked increase of infiltrating CD8+ T lymphocytes in three of 11 tumor biopsies analyzed. A partial response was observed in one patient with pancreatic carcinoma. Stable disease was observed in two patients and progression in eight patients, with two of the cases fast-progressing during treatment.

\section{Conclusion}

Intratumoral injection of DC transfected with an adenovirus encoding interleukin-12 to patients with metastatic gastrointestinal malignancies is feasible and well tolerated. Further studies are necessary to define and increase clinical efficacy.

\section{J Clin Oncol 23:999-1010. (C) 2005 by American Society of Clinical Oncology}

\section{INTRODUCTION}

Surgical resection is the only curative treatment available for gastrointestinal carcinomas. Unfortunately, a high proportion of patients are diagnosed when current therapies are largely ineffective.

Dendritic cells (DCs) ${ }^{1,2}$ are attractive adjuvants for therapeutic immunization of cancer patients. ${ }^{1,3}$ Immature DCs take up and process antigens ${ }^{4,5}$ and, upon maturation/activation, migrate to draining lymph nodes where they can prime tumor-antigen-specific CD4+ and CD8 + T cells. ${ }^{2,4,6}$ The DC maturation program includes: downregulation of their capacity to acquire antigens, increased expression of major histocompatibility complex and co-stimulatory 
molecules, changes in chemokine receptors, ${ }^{6,7}$ and enhanced production of key cytokines such as interleukin (IL) -2, IL-12, and IL-15. ${ }^{8-10}$ Besides, mature DCs have the ability to activate both natural killer $(\mathrm{NK})^{11}$ and NK T cells. ${ }^{12}$

For immunotherapy, tumor antigens are provided to DCs in different forms such as incubating DCs with synthetic or native peptides, tumor tissue lysates, ${ }^{13,14}$ purified proteins, ${ }^{15}$ tumor-derived total RNA, ${ }^{16}$ or by fusing malignant cells and DCs. ${ }^{17}$ Furthermore, the efficacy of DC-based immunotherapy may also be increased by transduction with either cytokine genes or co-stimulatory molecules (IL-2, IL-7, IL-12, secondary lymphoid-tissue chemokine, CD40-L) into DCs. ${ }^{18-24}$

IL-12 is a potent immunostimulatory cytokine, produced physiologically by DCs, which has shown properties as an anticancer agent in experimental tumors, as a recombinant protein, ${ }^{25}$ or in gene therapy approaches including delivery with transfected fibroblasts. ${ }^{26,27}$ Recently, we have reported that intratumoral injection of an adenovirus encoding for human IL-12 (AFIL-12) to 21 patients with advanced digestive malignancies was feasible and well tolerated. ${ }^{28} \mathrm{Up}$ to $3 \times 10^{12}$ viral particles exert mild antitumor effect (one partial response and six stable disease cases). Biologic effects included increases in serum interferon gamma (IFN- $\gamma$ ) and increases in the lymphocyte infiltrate in four of 10 patients.

We have previously demonstrated that repeated intratumor injections of murine bone-marrow-derived DC transfected with an adenovirus encoding IL-12 induce a potent antitumoral response. ${ }^{21,29}$ Importantly, this strategy not only eradicates the directly injected tumors, but also distant disease demonstrating systemic immunity. ${ }^{29}$ The activity of CD8 $+\mathrm{T}$ cells is crucial to achieve such a therapeutic effect. ${ }^{21,22,30}$

We decided clinical translation of this strategy with intratumoral maturing/semimature DCs,${ }^{31}$ despite the potential risk of inducing immunity to self antigens shared by normal and cancer tissues. ${ }^{32}$ Both our preclinical data and reports from several phase I/II studies were encouraging and demonstrated the safety of immunotherapy with DCs. ${ }^{3,33,34}$ Another potential drawback of this intratumoral route of administration is the presence of immunosuppressive factors at the tumor microenvironment that could endanger the performance of DCs even if transfected to produce IL-12. ${ }^{35-37}$ Recent observations have highlighted that under certain conditions tumor can exploit intratumoral DCs for their own growth. ${ }^{38}$ This article describes the first clinical experience of intratumoral administration of DCs engineered to produce IL- 12 by recombinant adenovirus, thus combining gene and cellular immunotherapy.

\section{PATIENTS AND METHODS}

\section{Study Design}

This was an open-label, nonrandomized, dose-escalation phase I trial in which DCs transfected with AFIL-12 were admin- istered intratumorally to patients with metastatic gastrointestinal carcinomas.

Objectives. The primary end point was to assess both feasibility and safety of direct intratumoral injections of DCs. Secondary end points were biologic effect and antitumor activity.

\section{Patient Selection and Enrollment}

Inclusion criteria included: (1) age $\geq 18$ years; (2) metastatic disease; (3) histologic diagnosis of primary liver cancer, colorectal cancer, or pancreatic cancer; (4) an Eastern Cooperative Oncology Group performance status $\leq 3$; and (5) an accessible tumor mass. Exclusion criteria included: (1) pregnancy or lactation; (2) neutrophil count $\leq 0.5 \times 10^{9} / \mathrm{L}$ or a platelet count $\leq 20 \times 10^{9} / \mathrm{L}$; (3) antiHIV antibodies; (4) an active infection; (5) contraindications for leukapheresis; (6) active autoimmune disease; and (7) immunosuppressive treatment within the last 4 weeks before the first dose. All patients provided signed informed consent. Permission was granted by the institutional ethical committee, the local government's ethical committee, and the Spanish Agency for the Evaluation of Medicinal Products.

\section{AFIL-12 and Generation of Monocyte-Derived DCs}

AFIL-12 was constructed and produced as described. ${ }^{28}$ Briefly, AFIL-12 is a first-generation, replication-defective adenovirus that encodes the human IL-12 genes under the transcriptional control of a nonselective cytomegalovirus promoter. AFIL-12 was expanded in 293 cells, purified by cesium chloride density gradient, dialyzed, and stored at $-80^{\circ} \mathrm{C}$. Clinical-grade AFIL- 12 with a viral particle plaque-forming units ratio of 12:65 was manufactured and certified by BioReliance (Glasgow, Scotland).

\section{Isolation of PBMC and Clinical-Grade Purification of CD14+ Cells}

Patients underwent a three-blood-volume leukapheresis (Cobe Spectra; Gambro BCT, Lakewood, CO ). CD14+ monocytes were isolated using immunomagnetic beads (CliniMACS; Miltenyi Biotec, Bergisch Gladbach, Germany). A fraction of $\mathrm{CD} 14+$ cells was slowly frozen to $-120^{\circ} \mathrm{C}$ in autologous serum with $10 \%$ volume/volume dimethylsulfoxide by using a cryofreezing container (CM-25, Carburos Metálicos, Spain) for next doses.

\section{Cultures and Transfection}

CD14 + cells $\left(10^{6} / \mathrm{mL}\right)$ were cultured at $37^{\circ} \mathrm{C}$ and $5 \% \mathrm{CO}_{2}$ in serum-free AIMV medium (GIBCO BRL, Grand Island, NY) containing 1,000 U/mL of IL-4 (R\&D Systems, Minneapolis, $\mathrm{MN}$ ) and $500 \mathrm{U} / \mathrm{mL}$ of granulocyte macrophage colony-stimulating factor (GM-CSF; Leucomax; Novartis, Basel, Switzerland). Cultures were supplemented with cytokines at days 3 and 5 . On day 7, cells were washed with serum-free RPMI 1640 medium, counted, and resuspended at $5 \times 10^{6}$ cells $/ \mathrm{mL}$ with AFIL-12 at a multiplicity of infection (MOI) of 1,000 during 2 hours at $37^{\circ} \mathrm{C}$. DCs were administered to patients 24 hours after transfection. Previous experiments had documented that transfection at MOI 1,000 with a similar adenovirus encoding the reporter gene $\beta$-galactosidase routinely gave rise to $70 \%$ to $80 \%$ $\beta$-galatosidase + cells. In the last four patients, the cells were exposed 24 hours before administration to $50 \mathrm{ng} / \mathrm{mL}$ of tumor necrosis factor alpha (TNF- $\alpha$; Boehringer, Ingelheim, Germany), 20 $\mu \mathrm{g} / \mathrm{mL}$ of prostaglandin $\mathrm{E}_{2}$ (Pharmacia, Uppsala, Sweden) and $1,000 \mathrm{U} / \mathrm{mL}$ of interferon alfa (IFN- $\alpha$; Schering-Plough, Dardilly, France) to enhance maturation. Maturation was confirmed 
assessing increases in the immunofluorescence of CD80, CD86, and human leukocyte antigen-DR (HLA-DR). Cell viability was confirmed by the tripan blue exclusion test. Flow cytometric analysis was performed at day 7 using FACScan (Becton Dickinson, San Diego, CA). Minimal quality criteria for DCs included $\geq 75 \%$ HLA-DR + and CD $11 c^{\text {bright }}$ and negative microbial tests. DC activity was confirmed in allogenic mixed lymphocyte reaction cultures.

\section{Treatment Plan}

Patients were enrolled consecutively in three cohorts of five patients each with the following dose-escalation plan: cohort 1: $10^{7}$ DCs; cohort 2: $2.5 \times 10^{7}$ DCs; cohort 3: $5 \times 10^{7}$ DCs. Two additional patients were included in the last cohort. Three doses of DCs were administered intratumorally at 21-day intervals. DCs were resuspended in saline and administered in one single tumor location under ultrasound (US), computed tomography $(\mathrm{CT})$ scan or endoscopic US guidance.

\section{Patient Evaluation}

Figure 1 summarizes the evaluation of the patients throughout the study. Appraisal before DC treatment also included Doppler echocardiogram and bone scintigraphy. In-patients were carefully monitored during the first 4 days after each treatment by daily evaluation of toxicity and a comprehensive set of hematologic and biochemical laboratory tests at days 0,1 , and 3 . On day 21 , a tissue sample was obtained from the injected lesion immediately before the administration of the second dose. At day 63, toxicity was reevaluated and response to therapy was assessed using WHO criteria. ${ }^{39}$ Dose-limiting toxicity was defined as grade 4 toxicity of any duration related to DCs or nonreversible grade 3 toxicity related to DCs. Toxicity was assessed throughout the study using the National Cancer Institute Common Toxicity Criteria. ${ }^{40}$ Relation to treatment of adverse reactions observed were classified as definite, probable, or possible according to Karch and Lasagna criteria. ${ }^{41}$

\section{Immunologic Monitoring}

Cytokine measurement. DCs $\left(10^{6} / \mathrm{mL}\right)$ were assayed for IL12 p70 production 24 and 48 hours after AFIL-12 infection using an enzyme-linked immunoabsorbent assay (ELISA) kit in the culture supernatant (Pharmingen, San Diego, CA). Simultaneous measurement of IL-6, IL-10, TNF- $\alpha$, and IL-12 in serum samples at baseline and on days $0,1,2$, and 3 after each dose of DCs from patients was analyzed by microparticle-based flow cytometry according to manufacturer's instructions (BD Bioscience, San Jose, CA). IFN- $\gamma$ levels were monitored by ELISA in serum samples at baseline and on days 0, 1, 2, and 3 after each dose of DCs (Pharmingen).

NK activity. Cytotoxic NK activity against K562 cells was measured by standard 5-hour sodium ${ }^{51}$ chromate-release assay as described. $^{30}$

Antiadenovirus antibodies measurement. Total and neutralizing antibody titers against adenovirus were monitored by ELISA and interference with infection by an adenovirus encoding luciferase, respectively, at baseline and just before the second and the third dose of DCs (manuscript in preparation).

Delayed-type hypersensitivity test. Delayed-type hypersensitivity (DTH) skin tests were used to assess in vivo immune reaction against autologous tumor antigens. Tumor tissue was placed in phosphate-buffered saline and a single-cell suspension was obtained. Cells were lysed by three to four freeze-and-thaw cycles and debris was removed by centrifugation for $10 \mathrm{~min}$ at 2,000 rpm. Supernatants were collected, irradiated at 5,000 rads and aliquots stored at $-80^{\circ} \mathrm{C}$. GM-CSF $50 \mu \mathrm{g}$ were added to each lysate solution. Skin tests were performed by $50 \mu \mathrm{l}$ intradermal injection of this tumor lysate when indicated in Figure 1. A solution containing AFIL-12 inactivated by ultraviolet light were injected to assess reactivity against viral antigens.

Pathologic studies. Tumor samples obtained at baseline and at day 21 were histopathologically analyzed as described. ${ }^{28}$ Surface area calculations were computer-assisted by image analysis software and positive cells were manually counted by a pathologist blinded to the identity of the samples.

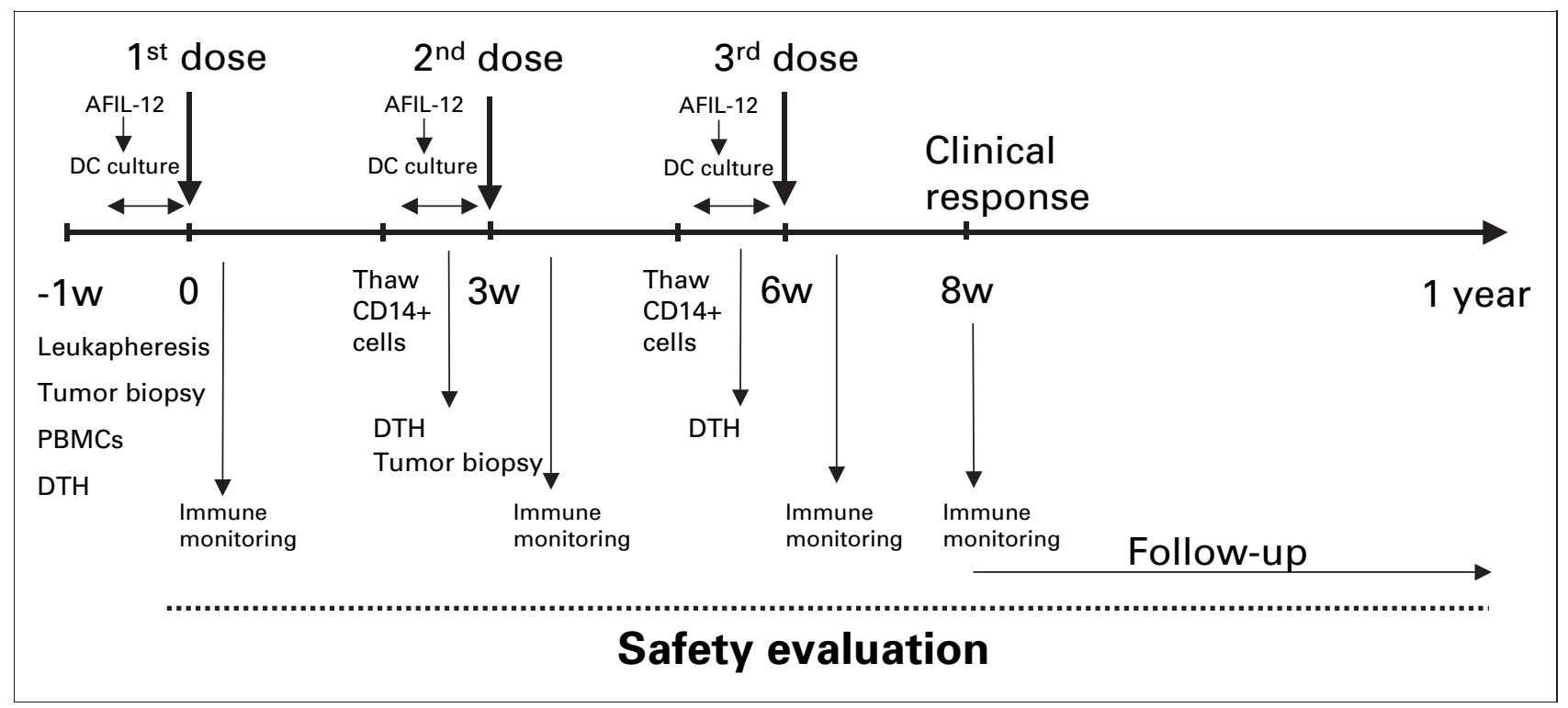

Fig 1. Flow-chart of the clinical trial design. Treated tumors were biopsied at day 21. AFIL-12, adenovirus encoding interleukin-12 genes; DC, dendritic cells; DTH, delayed-type hypersensitivity test; PBMC, peripheral blood mononuclear-cells; w, weeks. 


\begin{tabular}{|c|c|c|c|c|c|}
\hline Patient No. & Sex/Age (years) & Tumor Type & ECOG PS & Previous Therapy & Site of Metastases \\
\hline 1 & $\mathrm{M} / 44$ & PC & 0 & RT/chemo & $L, P, L N$ \\
\hline 2 & $\mathrm{~F} / 72$ & $\mathrm{HCC}^{*}$ & 0 & TACE/surg/EI & $\mathrm{L}$ \\
\hline 3 & $\mathrm{M} / 62$ & CRC & 1 & Surg/chemo/EI & $L, P$ \\
\hline 4 & $M / 63$ & CRC & 0 & Surg/chemo & L, Lu \\
\hline 5 & $\mathrm{M} / 72$ & $\mathrm{HCC}$ & 0 & $\mathrm{PEI} / \mathrm{TACE}$ & L, SC \\
\hline 6 & $M / 21$ & $\mathrm{HCC}$ & 2 & Chemo & L, Lu, LN \\
\hline 7 & $\mathrm{M} / 49$ & CRC & 2 & Surg/chemo/El & L, Lu \\
\hline 8 & M/39 & CRC & 2 & Surg/chemo & $L, B$ \\
\hline 9 & $F / 55$ & PC & 1 & RT/chemo & $P, L, L N$ \\
\hline 10 & $\mathrm{M} / 73$ & $\mathrm{HCC}^{*}$ & 0 & TACE & $\mathrm{L}$ \\
\hline 11 & $\mathrm{M} / 56$ & CRC & 0 & Surg/chemo & L, LN \\
\hline 12 & $M / 49$ & PC & 1 & RT/chemo & $P, L, L N$ \\
\hline 13 & $M / 69$ & $\mathrm{HCC}^{*}$ & 1 & TACE/surg/EI† & $L, B$, st \\
\hline 14 & $\mathrm{~F} / 68$ & $\mathrm{HCC}^{*}$ & 1 & Chemo & $\mathrm{L}, \mathrm{B}$ \\
\hline 15 & $\mathrm{~F} / 73$ & $\mathrm{HCC}^{*}$ & 0 & TACE & $\mathrm{L}$ \\
\hline 16 & M/39 & $\mathrm{HCC}^{*}$ & 1 & None & L, LN \\
\hline 17 & $M / 53$ & $\mathrm{ChC}$ & 2 & Chemo/RT & $L, B, L N$ \\
\hline \multicolumn{6}{|c|}{$\begin{array}{l}\text { Abbreviations: DC, dendritic cell; ECOG PS, Eastern Cooperative Oncology Group performance status; PC, pancreatic cancer; RT, radiotherapy; chemo, } \\
\text { chemotherapy; L, liver; P, pancreas; LN, lymph nodes; HCC, hepatocellular carcinoma; TACE, trans-arterial chemoembolization; surg, surgery; EI, } \\
\text { experimental immunotherapy; CRC, colorectal carcinoma; Lu, lung; PEl, percutaneous ethanol injection; B, bones; st, soft tissue; ChC, cholangiocarcinoma. } \\
{ }^{*} \text { Concurrent chronic hepatitis C viral infection. } \\
\text { †El including patients previously treated with adenovirus encoding interleukin-12 genes. }\end{array}$} \\
\hline
\end{tabular}

\section{RESULTS}

\section{Patient Characteristics}

Seventeen patients were enrolled between May 2002 and March 2004 (Table 1). Mean age was 56 years. Eight patients had hepatocellular carcinoma (HCC), three had pancreatic cancer (PC), five had colorectal cancer (CRC), one had cholangiocarcinoma ( $\mathrm{ChC}$ ), and all of them had metastatic disease. Six of the eight patients with HCC had underlying liver cirrhosis due to hepatitis $\mathrm{C}$ virus. All cirrhotic patients had portal hypertension and a fairly preserved liver function (five cases of ChildPugh class A and one case of class B). Patients with PC and CRC had had prior standard chemotherapy, whereas most HCC patients received multimodal therapy includ- ing surgery, transarterial embolization, or radiofrequency ablation.

\section{Generation of DCs}

Results of leukapheresis. Autologous DCs were differentiated in serum-free medium (AIM-V) from $\mathrm{CD} 14+$ monocytes. The immediate yield of thawed cells alive was above $90 \%$ and ranged from $40 \%$ to $78 \%$ (mean, 62\%) after 24 hours back in culture.

The number of DCs injected was $>75 \%$ of the planned dose in all patients. After 8 days of culture, harvested cells were consistently $100 \% \mathrm{CD} 11 \mathrm{c}$ bright, being nearly $50 \% \mathrm{CD} 1 \mathrm{a}+$, and expressed high levels of HLADR (75\%; Table 2) and intermediate levels of CD80 and CD86 (41\% and 44\%, respectively). These findings were

\begin{tabular}{|c|c|c|c|c|c|}
\hline Patient No. & CD11c & $\mathrm{CD} 1 \mathrm{a}$ & CD80 & CD86 & HLA-DR \\
\hline 1 & 99 & 57 & 33 & 49 & 50 \\
\hline 2 & 100 & 40 & 24 & 97 & 95 \\
\hline 3 & 100 & 49 & 23 & 58 & 54 \\
\hline 4 & 94 & 87 & 27 & 9 & 90 \\
\hline 5 & 100 & 36 & 54 & 94 & 98 \\
\hline 6 & 100 & 25 & 33 & 48 & 83 \\
\hline 7 & 100 & 78 & 37 & 16 & 96 \\
\hline 8 & 100 & 16 & 23 & 46 & 88 \\
\hline 9 & 100 & 82 & 35 & 23 & 41 \\
\hline 10 & 100 & 63 & 68 & 48 & 70 \\
\hline 11 & 100 & 66 & 68 & 36 & 43 \\
\hline 12 & 100 & 67 & 26 & 27 & 65 \\
\hline 13 & 99 & 31 & 36 & 17 & 80 \\
\hline 14 & 99 & 40 & 10 & 18 & 79 \\
\hline 15 & 100 & 40 & 72 & 65 & 64 \\
\hline 16 & 100 & 29 & 88 & 88 & 85 \\
\hline 17 & 100 & 88 & 46 & 14 & 94 \\
\hline Mean \pm SE & $99.47 \pm 0.36$ & $52.58 \pm 5.54$ & $41.35 \pm 5.19$ & $44.29 \pm 6.92$ & $75 \pm 4.62$ \\
\hline
\end{tabular}

Abbreviations: DCs, dendritic cells; HLA-DR, human leukocyte antigen-DR. 


\begin{tabular}{|c|c|c|c|c|}
\hline \multirow[b]{2}{*}{ Patient No. } & \multicolumn{2}{|c|}{ IL-12 (ng/mL/106 cells) } & \multicolumn{2}{|c|}{ Mean \pm SE } \\
\hline & 24 Hours & 48 Hours & 24 Hours & 48 Hours \\
\hline 1 & 7 & 39 & & \\
\hline 2 & 400 & 530 & & \\
\hline 3 & 14 & 160 & $98 \pm 41.45$ & $212.2 \pm 50.2$ \\
\hline 4 & 1.2 & 37 & & \\
\hline 5 & 68 & 295 & & \\
\hline 6 & 25 & 68 & & \\
\hline 7 & 0 & 164 & & \\
\hline 8 & 0 & 0 & $10.8 \pm 3.16$ & $117 \pm 30.35$ \\
\hline 9 & 25 & 313 & & \\
\hline 10 & 4 & 40 & & \\
\hline 11 & 2 & $3)$ & & \\
\hline 12 & 2.09 & 3.3 & & \\
\hline 13 & 3 & 10 & & \\
\hline 14 & 4 & 8 & $7.41 \pm 0.91$ & $21.47 \pm 1.67$ \\
\hline 15 & 11 & 20 & & \\
\hline 16 & 8 & 52 & & \\
\hline 17 & 22 & 54 & & \\
\hline \multicolumn{5}{|c|}{$\begin{array}{l}\text { NOTE. Supernatants from adenovirus IL-12 infected dendritic cells were } \\
\text { collected at } 24 \text { and } 48 \text { hours for quantification of IL-12 p70 by enzyme- } \\
\text { linked immunoabsorbent assay. Total IL-12 concentration in culture } \\
\text { supernatants are given. } \\
\text { Abbreviation: IL-12, interleukin-12. }\end{array}$} \\
\hline
\end{tabular}

consistent with a phenotype of intermediate maturity or "in process of maturation/activation."31

Production of $I L-12$. In vitro transfected DCs with AFIL-12 proved able to produce high amounts of IL-12 p70 at 24 and 48 hours (Table 3).

\section{Treatment Procedure}

Intratumoral injection of DCs was feasible in $100 \%$ of cases. As shown in Table 4, 43 injections were adminis-

\begin{tabular}{|c|c|c|c|}
\hline Dose (No. of DCs) & $\begin{array}{c}\text { Treatment } \\
\text { Courses }\end{array}$ & $\begin{array}{l}\text { Procedure of } \\
\text { Guidance }\end{array}$ & $\begin{array}{c}\text { Clinical } \\
\text { Response* }\end{array}$ \\
\hline \multicolumn{4}{|l|}{$10 \times 10^{6}$} \\
\hline \multicolumn{4}{|l|}{ Patient No. } \\
\hline 1 & 3 & US & PR \\
\hline 2 & 3 & US & PD \\
\hline 3 & 3 & US & PD \\
\hline 4 & 3 & US & PD \\
\hline 5 & 3 & US & PD \\
\hline \multicolumn{4}{|l|}{$25 \times 10^{6}$} \\
\hline \multicolumn{4}{|l|}{ Patient No. } \\
\hline 6 & 2 & US & NA \\
\hline 7 & 2 & US & NA \\
\hline 8 & 1 & US & NA \\
\hline 9 & 3 & EUS & PD \\
\hline 10 & 3 & US & SD \\
\hline \multicolumn{4}{|l|}{$50 \times 10^{6}$} \\
\hline \multicolumn{4}{|l|}{ Patient No. } \\
\hline 11 & 3 & US & PD \\
\hline 12 & 2 & $\mathrm{CT}$ & NA \\
\hline 13 & 3 & US & PD \\
\hline 14 & 2 & US & NA \\
\hline 15 & 3 & US & SD \\
\hline 16 & 3 & US & PD \\
\hline 17 & 1 & US & NA \\
\hline \multicolumn{4}{|c|}{$\begin{array}{l}\text { Abbreviations: DCs, dendritic cells; US, ultrasonography; PR, partial } \\
\text { response; PD, progressive disease; NA, not assessable; EUS, endo- } \\
\text { scopic US; SD, stable disease; CT, computed tomography. } \\
\text { *Tumor response was evaluated after the last treatment according to } \\
\text { WHO criteria. }\end{array}$} \\
\hline
\end{tabular}

tered to the 17 patients guided by either US $(\mathrm{n}=38)$, endoscopy US $(\mathrm{n}=3)$, or CT scan $(\mathrm{n}=2)$. Eleven patients underwent all of the three planned doses, with four patients receiving two injections and two patients receiving only one injection.

\section{Toxicity}

A total of 118 adverse events were recorded throughout the follow-up period (Table 5). In general, DC administration was well tolerated and dose-limiting toxicity was not reached. None of the patients withdrew from the study because of adverse events. Mild to moderate fever, responsive to common antipyretics, was observed 24 to 48 hours after DC injection in $65 \%$ of patients, irrespective of the dose of DCs. Temperature increase was associated frequently with malaise and occasionally with sweating.

Three patients experienced pain at the site of injection that resolved in all cases with analgesics. Five patients (29\%) had grade 1 vomiting after the treatment. One patient experienced an episode of confusion in association with a high dose of narcotic analgesics due to chronic pain. Another patient developed progressive encephalopathy due to portosystemic shunt and died 40 days after the first DC injection.

Six patients developed hypoalbuminemia after treatment that could be associated with fluid therapy and also to the concomitant cirrhosis. Grade 1/2 lymphopenia was the most frequent adverse event, appearing in 14 patients $(76 \%)$. Four grade 3 lymphopenia events were also documented. Grade 1/2 lymphopenia before treatment was common, but lymphocyte count almost invariably decreased at day 1 and returned to basal values by day 3. Mild neutropenia was observed in three patients.

\begin{tabular}{|c|c|c|c|c|}
\hline \multirow[b]{2}{*}{ Event } & \multicolumn{3}{|c|}{ Grade } & \multirow[b]{2}{*}{ Relation to DC } \\
\hline & $1-2$ & 3 & 4 & \\
\hline Lymphopenia & 20 & 4 & 0 & Definite \\
\hline Fever & 19 & & 0 & Definite \\
\hline Sweating & 3 & & 0 & Definite \\
\hline Colostasis & 4 & & 0 & Possible \\
\hline Vomiting & 6 & & 0 & Probable \\
\hline Hyperbilirubinemia & 5 & & 0 & Probable \\
\hline Malaise & 8 & & 0 & Definite \\
\hline Leukopenia & 5 & & 0 & Probable \\
\hline Hypoalbuminemia & 6 & & 0 & Possible \\
\hline Anemia & 4 & & 0 & Possible \\
\hline Pain at site of injection & 3 & & 0 & Probable \\
\hline Neutropenia & 3 & & 0 & Probable \\
\hline Nausea & 2 & & 0 & Probable \\
\hline Vitiligo & 1 & & 0 & Probable \\
\hline \multicolumn{5}{|c|}{$\begin{array}{l}\text { NOTE. Adverse events observed between days } 1 \text { and } 45 \text { after } \\
\text { administration of dendritic cells. Adverse events were determined } \\
\text { using the National Cancer Institute Common Toxicity Criteria version } \\
\text { 2.0. Relation to dendritic cell administration was classified as definite, } \\
\text { possible, or unlikely according to Karch and Lasagna. }{ }^{41} \\
\text { Abbreviation: DC, dendritic cell. }\end{array}$} \\
\hline
\end{tabular}


No significant deterioration in hepatic function was observed in cirrhotic patients $(\mathrm{n}=8)$. However, five patients (four with HCC) had a transient, mild hyperbilirubinemia shortly after treatment. Among patients receiving multiple doses, side effects usually recurred, but cumulative toxicity was not observed. In addition, there was no clinical evidence of long-term toxicity among patients followed for more than 6 months.

No clinical manifestations of autoimmune reactions were observed with the exception of patient 5 , who developed two small vitiligo lesions in the forehead after the third dose of DCs. However, serum autoantibodies became detectable or increased their titer in five cases (Table 6).

\section{Biologic Response}

Systemic production of cytokines. There was no significant increase in serum IL-12 after treatment (not shown). In contrast, serum IFN- $\gamma$ increased after each dose of DCs reaching the maximum level at day $1 / 2$ after treatment (Fig 2). IFN- $\gamma$ concentrations appeared to be dose dependent, ranging from $100 \mathrm{pg} / \mathrm{mL}$ in cohort 1 to $500 \mathrm{pg} / \mathrm{mL}$ in cohort 3. Although it is possible that released IFN- $\gamma$ could be the result of an unspecific immune re-

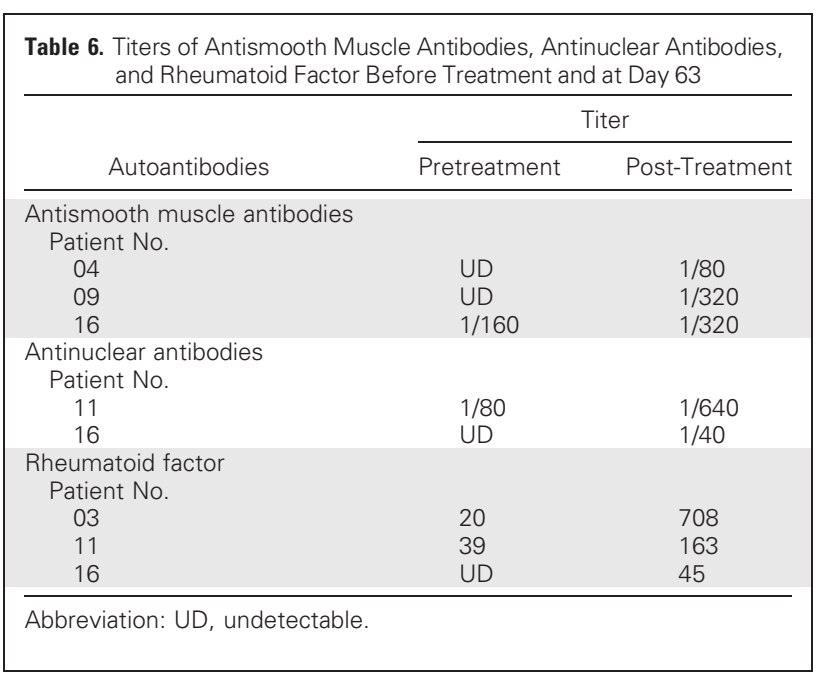

sponse against adenovirus, part of the IFN- $\gamma$ detected systemically could be the consequence of the expression of IL-12 as a transgene, because DCs were injected when they were producing high amounts of IL-12 (Table 3). There was a great heterogeneity in the production of

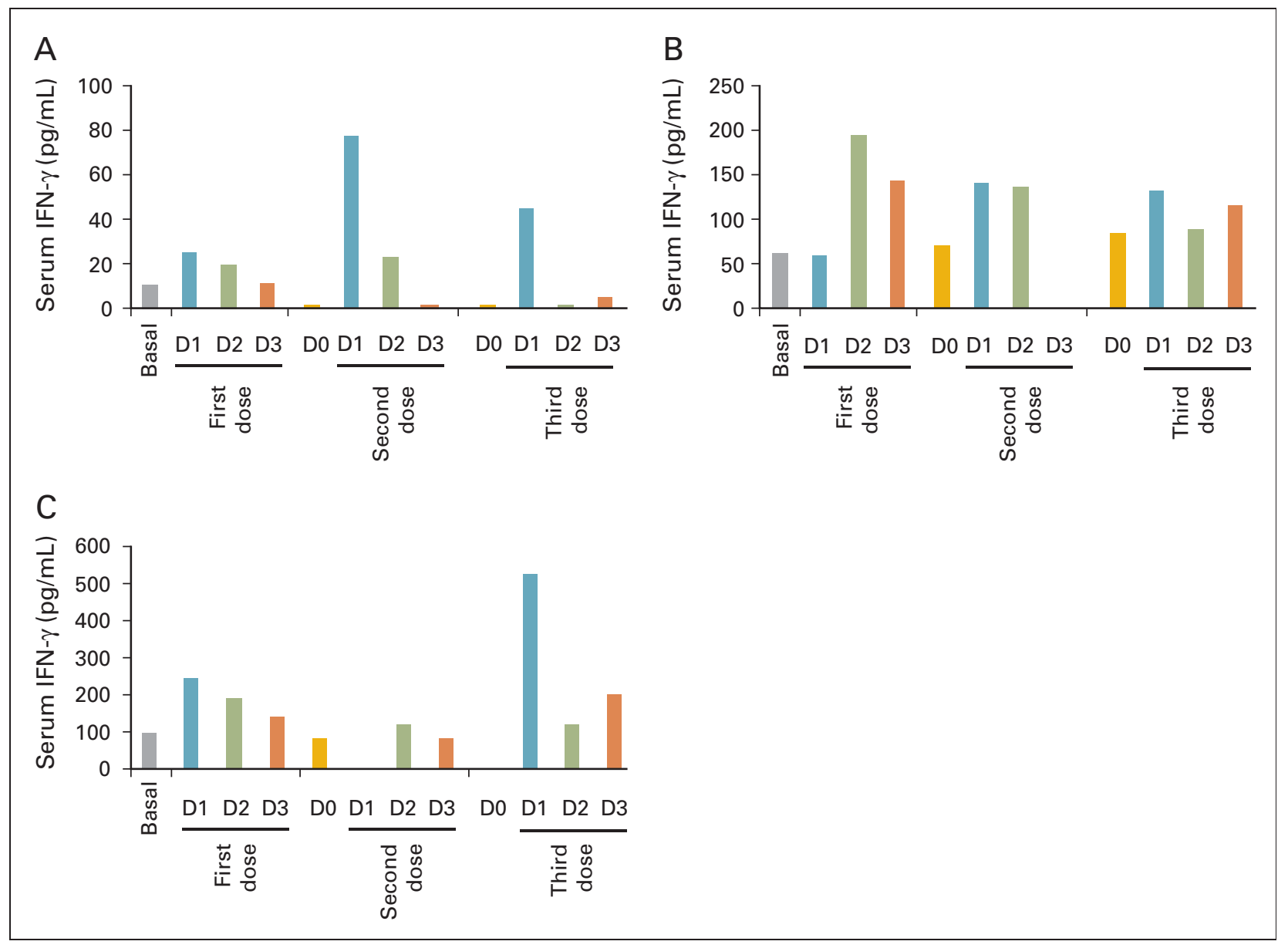

Fig 2. Increases in serum interferon gamma (IFN- $\gamma$ ) levels were detected in most patients after each DC dose (median). (A) Cohort 1; (B) cohort 2; (C) cohort 3. 
IL-12 in vitro by transfected DCs and, intriguingly, there was no correlation between the amount of IL-12 produced in vitro and the serum concentration of IFN- $\gamma$.

In addition, there was a dose dependent systemic production of IL-6 in the majority of patients (Fig 3). It is well known that IL-6 is produced in the context of an antiadenovirus immune response, but IL- 6 is also induced by IL12 and could contribute to enhance immune responses. ${ }^{42}$

NK-cell activity. Before DC administration, NK activity was low or undetectable (Fig 4). Five patients developed increases of peripheral blood NK activity after treatment. Among patients who showed increased NK ac- tivity, one patient achieved a partial response and another patient experienced a clear stabilization of her disease (patient No. 15).

Antiadenovirus antibodies. To explore the possibility that DCs infected with an adenovirus encoding IL-12 gene may immunize against viral antigens, we measured antibodies against adenovirus. All patients had high preexisting levels of total and neutralizing antiadenovirus antibodies (Fig 5). The great majority of patients increased the titer of antibodies against adenovirus after DC injection in a dose-dependent fashion. It should be noted that DCs were extensively washed before injection and, accordingly,
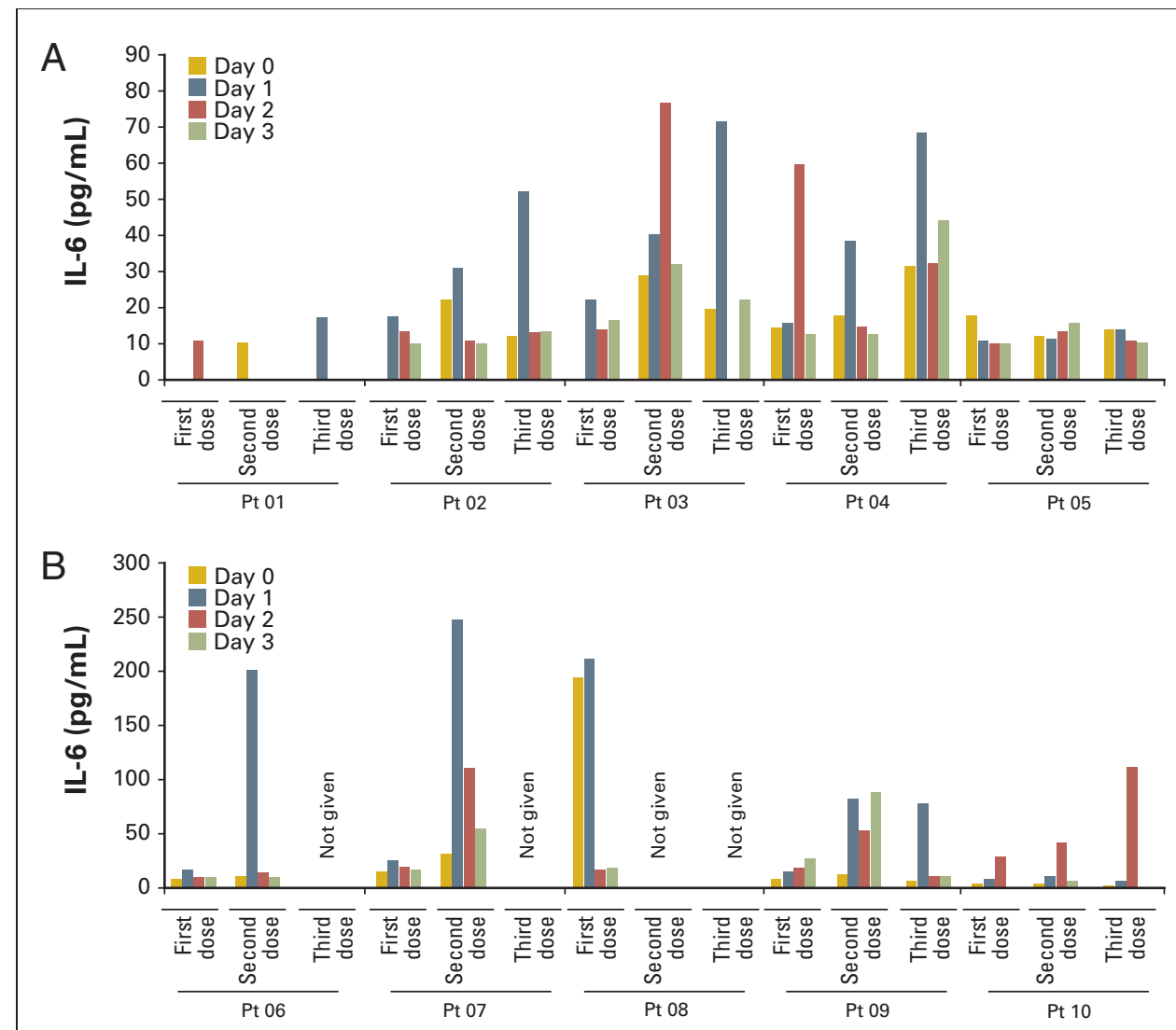

Fig 3. Serum interleukin-6 (IL-6) levels induced after each treatment. (A) Cohort 1; (B) cohort 2; (C) cohort 3. Pt, patient.

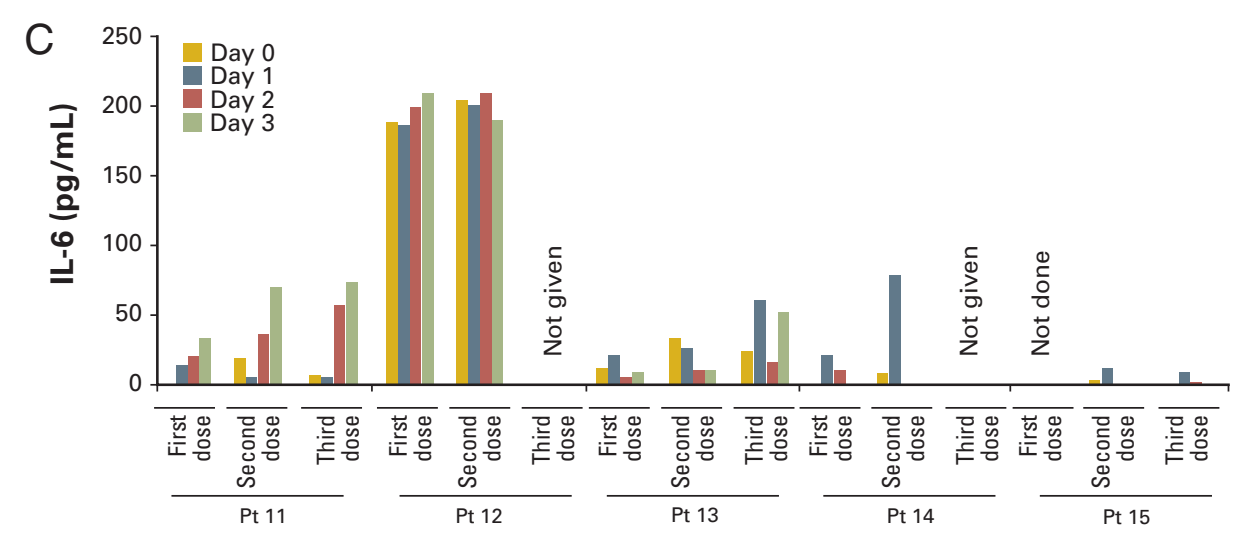




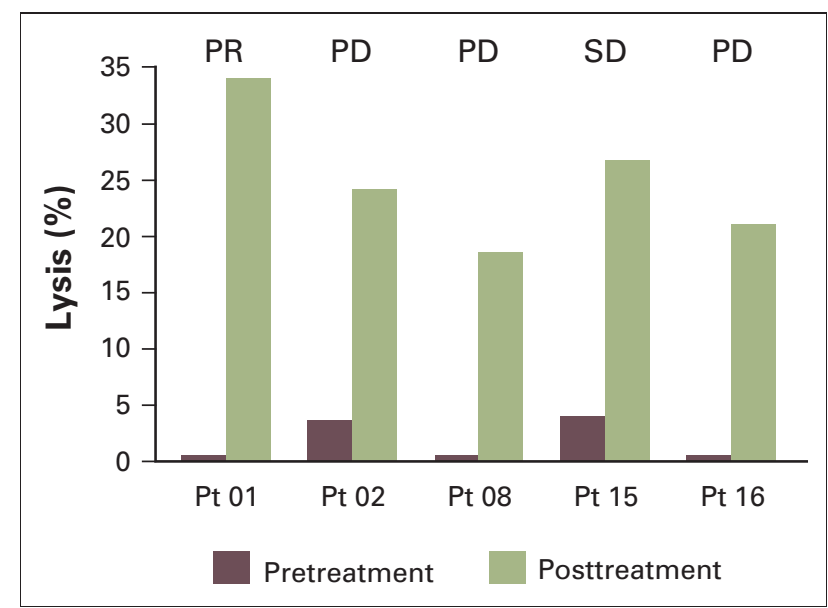

Fig 4. Natural killer (NK) -cell activity. NK-cell activity against K562 of peripheral blood mononuclear-cells of indicated patients, as evaluated before and after dendritic cell treatment (effector/target ratio:100). PR, partial response; $\mathrm{PD}$, progressive disease; $\mathrm{SD}$, stable disease; $\mathrm{Pt}$, patient.

only internalized or strongly DC-absorbed viral particles should have remained in the injected doses. These results suggest an adjuvant activity of DCs for boosting antibody production.

DTH tests. DTH skin test reactivity towards tumor extracts were negative in 13 patients assessed, the only exception being a weak positive reaction in patient No. 10 that declined 1 week later. However, the reaction against inactivated AFIL-12 was positive in all patients after therapy.
Pathologic study. A tumor sample was obtained at day 21 in all but three patients. The quality of samples permitted comparison of the two specimens in 11 patients. In five of these cases (patients 10,11, 13, 15, and 16; all of them had HCC), there was a substantial augmentation of the tumor infiltration by lymphocytes, with increases in CD3 and CD8 cells ranging from 51\% to 344\% and from $28 \%$ to $325 \%$, respectively (Fig 6A). Importantly, patients 10 and 15 experienced stabilization of their metastatic disease. As an example, Figure 6B shows immunohistochemical staining for CD8 + lymphocytes in tumor tissue sections from patient 10 . In the remaining six patients, there were no significant changes in the level of lymphocyte infiltration (not shown).

\section{Antitumor Response}

Response to therapy was evaluated at day 63 in 11 of 17 patients. Two patients with CRC, patients 7 and 8, withdrew from the study due to rapid progression of their liver metastases before receiving second and third dose of DCs, respectively. One patient with PC (patient 12) developed peritoneal carcinomatosis and tense ascitis and was excluded from the study shortly after the second dose of DCs. Another patient with metastatic $\mathrm{ChC}$ died prematurely after a sudden development of a Budd-Chiari syndrome and liver failure due to an aggressive procoagulant state. Patient 6 was not evaluated because he died before the administration of the third dose of DC due to encephalopathy and noninfectious refractory fever. Hence, only

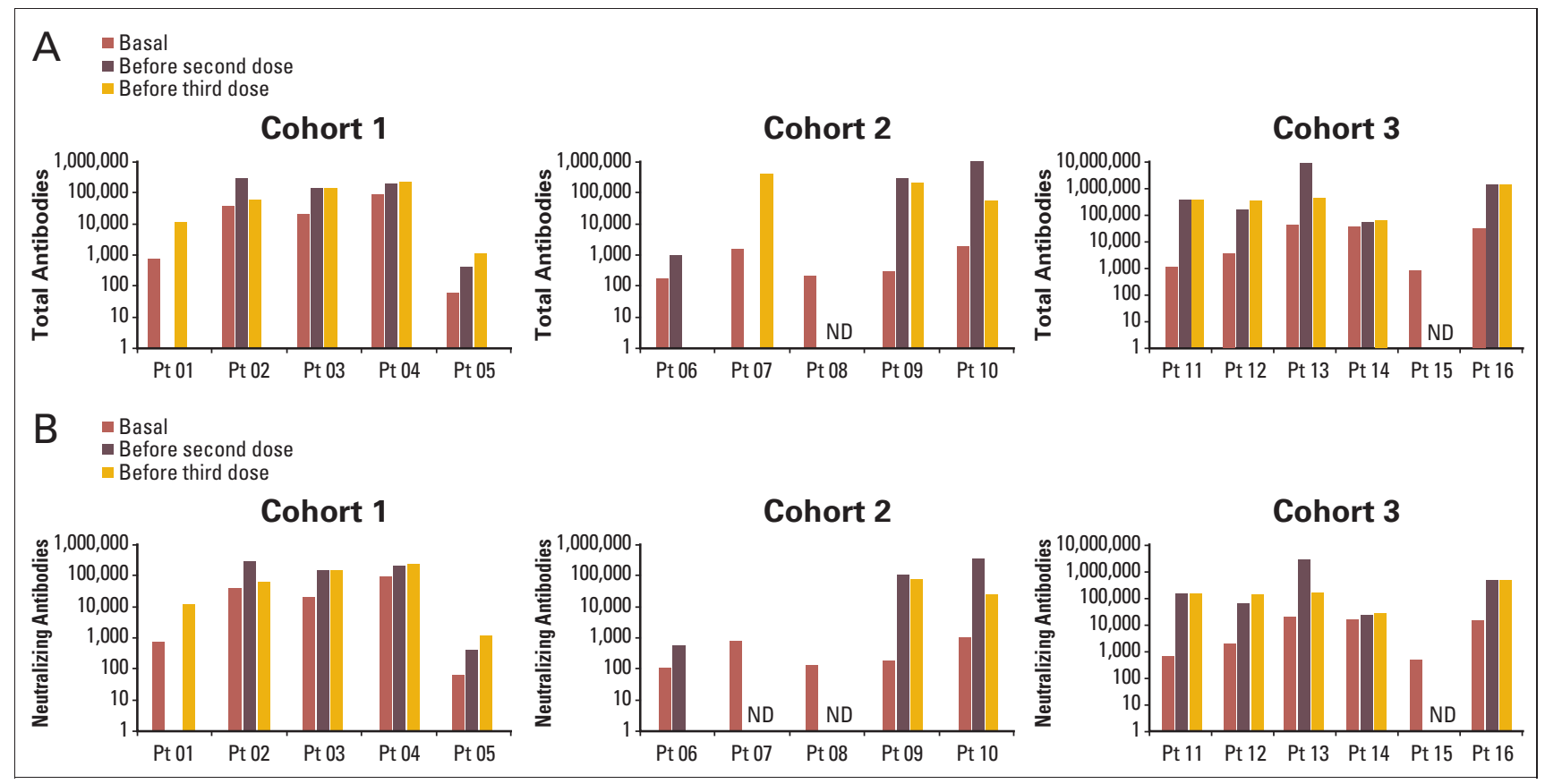

Fig 5. Antiadenovirus antibodies. All patients demonstrated a rise in antibody titers in response to dendritic cell treatment. (A) Total antibodies; (B) neutralizing antibodies. ND, not done; Pt, patient. 


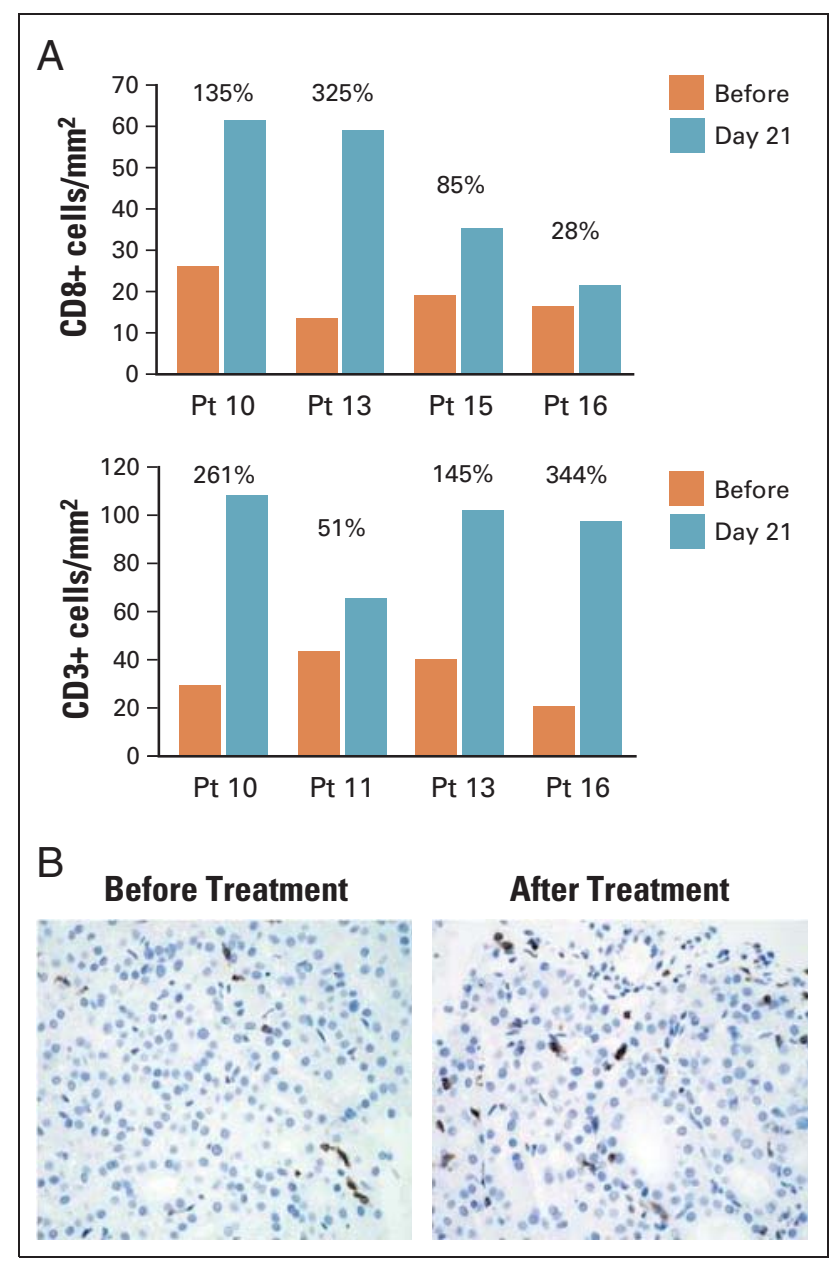

Fig 6. Inflammatory response at the tumor injection site. (A) Quantitation of $\mathrm{CD} 3+$ and $\mathrm{CD} 8+\mathrm{T}$ cells from treated tumor biopsies (\% of increase shown above the bars); and (B) biopsy of patient (Pt) 10 taken after dendritic cell injection (at day 21) demonstrate an increase in tumor-infiltrating lymphocytes labeling with CD8 antibody. Original magnification, $\times 200$.

11 patients received complete treatment and were assessed for antitumoral response. Two patients with metastatic HCC showed stable disease and eight patients showed tumor progression. A partial response was observed in patient 1, who had metastatic PC that had progressed even after radiochemotherapy. He received three doses of $10 \times 10^{6}$ DCs into primary tumor mass and a reduction in the number of noninjected liver metastases was obtained. Importantly, the response persisted more than 3 months. Figure 7 shows abdominal CT scans from this patient taken before and after three injections of DCs. Remission lasted 3 months but duodenal obstruction due to primary tumor progression developed at that time.

Patient 4 with CRC showed a significant decrease in serum levels of carcinoembryonic antigen without CT scan evidence of response or stabilization. In contrast, DC treatment was followed by an increase of carcinoem- bryonic antigen in patients 7 and 8 with progression of their liver metastases from CRC.

\section{DISCUSSION}

In this study we demonstrate for the first time that intratumoral administration of DCs engineered to produce IL12 by recombinant adenovirus is both feasible and safe in humans.

We, and others, have previously shown that intratumoral injection of bone marrow-derived dendritic cells engineered to produce IL-12 by means of viral vectors ${ }^{21,22}$ induces a potent immune response in mice. In these animals, neither toxicity nor any sign of autoimmunity were ever found. ${ }^{21,22,29}$

We have recently finished a phase I study in which patients with advanced digestive carcinomas safely received direct intratumoral injections of AFIL-12. ${ }^{28}$ Hence, this previous study provided us with key information about the safety of the viral vector at much higher doses than those used to transfect DC. ${ }^{28}$

Clinical trials with DCs loaded with peptide or tumor lysate, that include experience with gastrointestinal carcinomas, show increases in T-cell-mediated specific immunity against the tumor antigens used in these vaccines. ${ }^{14,34,43-46}$ The intratumoral route of administration sounds attractive because T-cell-defined tumor antigens have been identified for only a minority of human cancers $^{47}$ and because in certain tumors, such as digestive tumors, it is difficult to obtain sufficient malignant cells as a source of antigen. The idea of injecting DCs intratumorally pursues artificial tumor antigen cross-priming, ${ }^{4,5}$ resembling physiologic antigen presentation. ${ }^{6}$ However, exposure of DCs to the suppressive local environment might be a serious pitfall. In fact, local effects of transforming growth factor beta, vascular endothelial growth factor, IL-10, and prostaglandins on injected DCs might seriously damage their functional capabilities. ${ }^{35,36,48}$ Nonetheless, results obtained in mice strongly suggest that intratumoral administrations might be more efficacious than all the intravenous and subcutaneous routes when tested in parallel. ${ }^{49,50}$ Unfortunately, those studies did not include direct comparisons with intranodal release of DCs, as it is being performed in various clinical trials. ${ }^{14,31,34}$

Despite the purity of magnetic bead-selected monocytes, the resulting phenotype of DCs after 7 days of culture in the presence of IL-4 and GM-CSF was heterogeneous with regard to CD1a and other surface markers, indicating individual variability in the differentiation culture from monocytes even in defined serum-free medium. Moreover, there was a remarkable heterogeneity in the production of IL-12 after transfection with AFIL-12. This could be explained by an individual susceptibility of DCs to adenoviral transduction that can be genetically determined. ${ }^{51}$ 


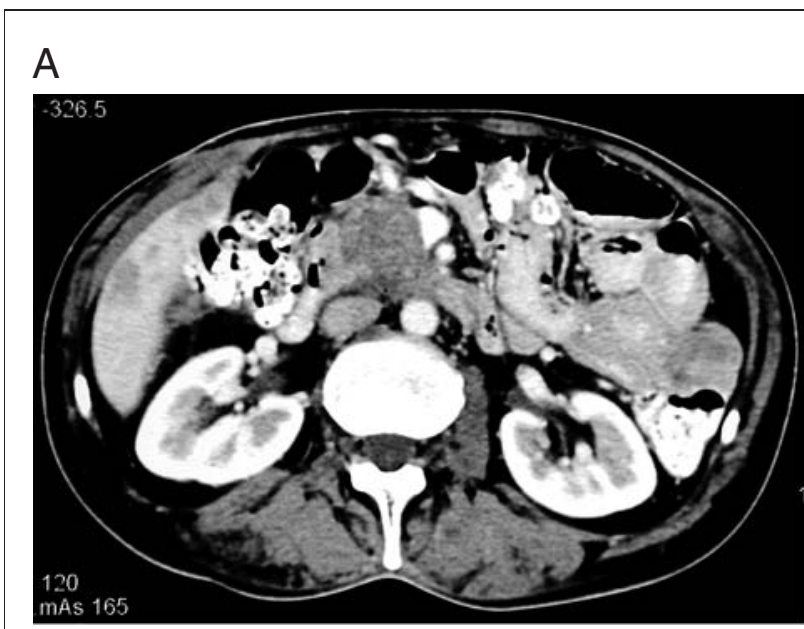

B

Fig 7. Clinical response to dendritic cell (DC) treatment. Computed tomography scans of patient 1 with metastatic pancreatic carcinoma who showed partial regression of liver metastases after the third dose of DCs injected into the primary tumor (A) before treatment and (B) after treatment.

Adenovirus transfection is known to elicit partial maturation of DCs, ${ }^{52,53}$ but we sought to further push the maturation program of the DCs with the TNF- $\alpha$, prostaglandin $\mathrm{E}_{2}$, and IFN- $\alpha$ cocktail in the last three patients. Such matured DCs had a profile of safety and biologic activity comparable to those that did not undergo this maturation culture, without any remarkable clinical difference.

DC doses elicited systemic production of IFN- $\gamma$ in a dose-dependent manner. Serum IFN- $\gamma$ was not clearly correlated, with neither clinical response nor with toxicity. Serum concentrations of IL- 6 had a comparable response pattern. However, IL- 6 can be suppressive of IFN- $\gamma$ functions by inducing suppressor of cytokine signaling- $1^{54}$ and signal transducer and activator of transcription-3. Hence, it remains to be seen whether IL- 6 triggered by our treatment is beneficial or pernicious. Five of 15 patients developed increases of NK activity in peripheral blood after treatment that could be related to well-described effects of IL-12 on NK cells, as well as to DCs' cross talk with NK cells. ${ }^{11,30}$ A recent report shows the critical role of IL-12 in the activation of NK cells through membrane contact. ${ }^{55}$ Among the cases experiencing this transient increase of NK activity, one patient underwent a partial response and another patient had stabilization of her disease. Moreover, we have observed an increment in NK activity in patients 1 , 2,8 , and 15, who experienced high concentrations of IFN- $\gamma$ after treatment suggesting a potential correlation between both phenomena. Therefore, either direct cytotoxicity or proinflammatory functions of NK cells might be involved in beneficial effects of the treatment.

We found a substantial increase in the amount of both $\mathrm{CD} 3+$ and $\mathrm{CD} 8+\mathrm{T}$ lymphocytes infiltrating the tumor in four of 11 patients after a single dose of DCs. Although two of these patients experienced stabilization of their tumor le- sions, further studies will address whether infiltrating lymphocytes were specific for any tumor antigen and whether they are endowed with cytolytic effector machinery.

A comparison of these biologic effects with those observed upon intratumoral injection of AFIL-12 indicate that there is an additional effect mediated by DCs, at least in terms of IFN- $\gamma$ secretion and NK cell activation. ${ }^{55}$

Evaluation of the T-cell immunity against tumors was an extremely difficult task due to the limited access to biopsy antigenic material. In two cases, there are data showing increased ELISPOT reactivity to tumor lysate. However, the limited amount of this tumor material precludes repetition and extension of these observations to a sufficient number of patients as to draw firm conclusions. On the contrary, reactivity to adenoviral capsides was evident in all eight studied cases both by DTH and by IFN- $\gamma$ ELISPOT (not shown).

Patients increased antibody titers against adenovirus, most of which were able to neutralize infection by this viral vector. This fact further supports experiments in rodents suggesting that DCs carrying absorbed viral particles act as adjuvant for antibody responses. ${ }^{56}$ In our case, adenoviral transfected DCs carry much less viral particles than those used in the previous trial and, by contrast, the increases in antibody titer are higher, indicating adjuvant activity of DCs.

Our studies offer solid ground to support that intratumoral injection of up to $5 \times 10^{7}$ DCs in patients with metastatic disease, including patients with advanced cirrhosis, is safe. Of note, one patient developed mild vitiligo that was not associated with any other sign of autoimmunity or any rise in the titer of autoantibodies. In this regard, increments in the titer of antismooth muscle antibodies, antinuclear antibodies, or rheumatoid factor 
were observed in five patients, but no clinical signs of autoimmunity have been recorded, as it has been the case in other DC-based protocols. ${ }^{3}$

The preliminary appraisal of clinical efficacy included one partial response and two cases of stable disease. If compared with the previous clinical trial using intratumoral AFIL-12, the clinical results were comparable, although more cases showed tumor stabilizations in the previous one. However, the second study recruited patients with more advanced and metastatic disease. Two lines of research can be fruitful to improve these effects: (1) introducing changes to fight the immunosupressive tumor microenvironment, such as local radiotherapy ${ }^{57}$ or molecular interference with DC-suppressing factors (TGF- $\beta$, IL-8, vascular endothelial growth factor); and (2) to further enhance the elicited immune response with cytokines ${ }^{58}$ or immunostimulating monoclonal antibodies. ${ }^{29,59,60}$ Better clinical results would probably be seen in patients with resectable tumors and microscopic residual disease at high risk of recurrence.

\section{Acknowledgment}

We thank Maria Eugenia Cornet, Maria del Mar Municio, and Elena del Corral for their work in trial monitoring, and Blanca Larrea for providing nursing care for patients. G. Gonzalez-Aseguinolaza, J.J. Lasarte, P. Sarobe, and J. Larrache are acknowledged for critical reading of the manuscript, as are Cell Therapy Unit staff for technical assistance.

\section{Authors' Disclosures of Potential Conflicts of Interest}

The authors indicated no potential conflicts of interest.

\section{REFERENCES}

1. Ardavin C, Amigorena S, Reis e Sousa C: Dendritic cells: Immunobiology and cancer immunotherapy. Immunity 20:17-23, 2004

2. Banchereau J, Briere F, Caux C, et al: Immunobiology of dendritic cells. Annu Rev Immunol 18:767-811, 2000

3. Figdor CG, de Vries IJ, Lesterhuis WJ, et al: Dendritic cell immunotherapy: Mapping the way. Nat Med 10:475-480, 2004

4. Heath WR, Carbone FR, Banchereau J, et al: Cross-presentation, dendritic cells, tolerance and immunity. Immunobiology of dendritic cells. Annu Rev Immunol 19:47-64, 2001

5. Arina A, Tirapu I, Alfaro $C$, et al: Clinical implications of antigen transfer mechanisms from malignant to dendritic cells. Exploiting cross-priming. Exp Hematol 30:1355-1364, 2002

6. Guermonprez P, Valladeau J, Zitvogel L, et al: Antigen presentation and T cell stimulation by dendritic cells. Annu Rev Immunol 20:621667, 2002

7. Sallusto $F$, Lanzavecchia A: Understanding dendritic cell and T-lymphocyte traffic through the analysis of chemokine receptor expression. Immunol Rev 177:134-140, 2000

8. Granucci F, Andrews DM, Degli-Esposti MA, et al: IL-2 mediates adjuvant effect of dendritic cells. Trends Immunol 23:169-171, 2002

9. Macatonia SE, Hosken NA, Litton M, et al: Dendritic cells produce IL-12 and direct the development of Th1 cells from naive CD4+ T cells. J Immunol 154:5071-5079, 1995

10. Jonuleit H, Wiedemann K, Muller G, et al: Induction of IL-15 messenger RNA and protein in human blood-derived dendritic cells: A role for IL15 in attraction of T cells. J Immunol 158:26102615, 1997

11. Zitvogel L: Dendritic and natural killer cells cooperate in the control/switch of innate immunity. J Exp Med 195:F9-14, 2002
12. Fujii $S$, Shimizu K, Smith $C$, et al: Activation of natural killer $T$ cells by alpha-galactosylceramide rapidly induces the full maturation of dendritic cells in vivo and thereby acts as an adjuvant for combined CD4 and CD8 T cell immunity to a coadministered protein. J Exp Med 198:267-279, 2003

13. Mayordomo JI, Zorina T, Storkus WJ, et al: Bone marrow-derived dendritic cells pulsed with synthetic tumour peptides elicit protective and therapeutic antitumour immunity. Nat Med 1:1297-1302, 1995

14. Nestle FO, Alijagic S, Gilliet $M$, et al: Vaccination of melanoma patients with peptideor tumor lysate-pulsed dendritic cells. Nat Med 4:328-332, 1998

15. Paglia $P$, Chiodoni $C$, Rodolfo $M$, et al: Murine dendritic cells loaded in vitro with soluble protein prime cytotoxic $\mathrm{T}$ lymphocytes against tumor antigen in vivo. J Exp Med 183:317-322, 1996

16. Gilboa E, Vieweg J: Cancer immunotherapy with mRNA-transfected dendritic cells Immunol Rev 199:251-263, 2004

17. Gong J, Chen D, Kashiwaba M, et al: Induction of antitumor activity by immunization with fusions of dendritic and carcinoma cells. Nat Med 3:558-561, 1997

18. Kirk CJ, Mule JJ: Gene-modified dendritic cells for use in tumor vaccines. Hum Gene Ther 11:797-806, 2000

19. Tirapu I, Rodriguez-Calvillo M, Qian C, et al: Cytokine gene transfer into dendritic cells for cancer treatment. Curr Gene Ther 2:79-89, 2002

20. Sharma S, Batra RK, Yang SC, et al: Interleukin-7 gene-modified dendritic cells reduce pulmonary tumor burden in spontaneous murine bronchoalveolar cell carcinoma. Hum Gene Ther 14:1511-1524, 2003

21. Melero I, Duarte M, Ruiz J, et al: Intratumoral injection of bone-marrow derived dendritic cells engineered to produce interleukin-12 induces complete regression of established murine transplantable colon adenocarcinomas. Gene Ther 6:1779-1784, 1999
22. Nishioka $Y$, Hirao $M$, Robbins $P D$, et al: Induction of systemic and therapeutic antitumor immunity using intratumoral injection of dendritic cells genetically modified to express interleukin 12. Cancer Res 59:4035-4041, 1999

23. Yang SC, Hillinger $S$, Riedl $K$, et al: Intratumoral administration of dendritic cells overexpressing CCL21 generates systemic antitumor responses and confers tumor immunity. Clin Cancer Res 10:2891-2901, 2004

24. Kikuchi T, Moore MA, Crystal RG: Dendritic cells modified to express CD40 ligand elicit therapeutic immunity against preexisting murine tumors. Blood 96:91-99, 2000

25. Trinchieri G: Interleukin-12 and the regulation of innate resistance and adaptive immunity. Nat Rev Immunol 3:133-146, 2003

26. Tahara $H$, Lotze $M T$, Robbins PD, et al: IL12 gene therapy using direct injection of tumors with genetically engineered autologous fibroblasts. Hum Gene Ther 6:1607-1624, 1995

27. Mazzolini G, Prieto J, Melero I: Gene therapy of cancer with interleukin-12. Curr Pharm Des 9:1981-1991, 2003

28. Sangro B, Mazzolini G, Ruiz J, et al: Phase I trial of intratumoral injection of an adenovirus encoding interleukin-12 for advanced digestive tumors. J Clin Oncol 22:1389-1397, 2004

29. Tirapu I, Arina A, Mazzolini G, et al: Improving efficacy of interleukin-12-transfected dendritic cells injected into murine colon cancer with anti-CD137 monoclonal antibodies and alloantigens. Int J Cancer 110:51-60, 2004

30. Rodriguez-Calvillo M, Duarte M, Tirapu I, et al: Upregulation of natural killer cells functions underlies the efficacy of intratumorally injected dendritic cells engineered to produce interleukin12. Exp Hematol 30:195-204, 2002

31. Gilliet M, Kleinhans $M$, Lantelme $E$, et al: Intranodal injection of semimature monocytederived dendritic cells induces $\mathrm{T}$ helper type 1 responses to protein neoantigen. Blood 102:3642, 2003

32. Ludewig B, Ochsenbein AF, Odermatt B, et al: Immunotherapy with dendritic cells di- 
rected against tumor antigens shared with normal host cells results in severe autoimmune disease. J Exp Med 191:795-804, 2000

33. Peterson AC, Harlin $H$, Gajewski TF: Immunization with melan-A peptide-pulsed peripheral blood mononuclear cells plus recombinant human interleukin-12 induces clinical activity and T-cell responses in advanced melanoma. J Clin Oncol 21:2342-2348, 2003

34. Stift A, Friedl J, Dubsky $P$, et al: Dendritic cell-based vaccination in solid cancer. J Clin Oncol 21:135-142, 2003

35. Gorelik L, Flavell RA: Transforming growth factor-beta in T-cell biology. Nat Rev Immunol 2:46-53, 2002

36. Gabrilovich DI, Ishida T, Nadaf $S$, et al: Antibodies to vascular endothelial growth factor enhance the efficacy of cancer immunotherapy by improving endogenous dendritic cell function. Clin Cancer Res 5:2963-2970, 1999

37. Dranoff G: Cytokines in cancer pathogenesis and cancer therapy. Nat Rev Cancer 4:1122, 2004

38. Conejo-Garcia JR, Benencia F, Courreges $M C$, et al: Tumor-infiltrating dendritic cell precursors recruited by a beta-defensin contribute to vasculogenesis under the influence of Vegf-A. Nat Med 10:950-958, 2004

39. WHO: Handbook of reporting results of cancer treatment. Publication No. 48. Geneva, Switzerland, WHO, 1979

40. National Cancer Institute: Guidelines for the reporting of adverse drug reactions. Bethesda MD, National Cancer Institute, 1990, pp 1-80

41. Karch FE, Lasagna $L$ : Adverse drug reactions. A critical review. JAMA 234:1236-1241, 1975

42. Diehl S, Rincon M: The two faces of IL-6 on Th1/Th2 differentiation. Mol Immunol 39:531536, 2002

43. Fong $L$, Hou $Y$, Rivas $A$, et al: Altered peptide ligand vaccination with Flt3 ligand expanded dendritic cells for tumor immunotherapy. Proc Natl Acad Sci USA 98:8809-8814, 2001

44. Thurner B, Haendle I, Roder C, et al: Vaccination with mage-3A1 peptide-pulsed mature, monocyte-derived dendritic cells expands specific cytotoxic $T$ cells and induces regression of some metastases in advanced stage IV melanoma. J Exp Med 190:1669-1678, 1999

45. Slingluff $C L$, Jr., Petroni GR, Yamshchikov GV, et al: Clinical and immunologic results of a randomized phase II trial of vaccination using four melanoma peptides either administered in granulocyte-macrophage colony-stimulating factor in adjuvant or pulsed on dendritic cells. J Clin Oncol 21:4016-4026, 2003

46. Iwashita Y, Tahara K, Goto S, et al: A phase I study of autologous dendritic cell-based immunotherapy for patients with unresectable primary liver cancer. Cancer Immunol Immunother 52:155-161, 2003

47. Gilboa $\mathrm{E}$ : The promise of cancer vaccines Nat Rev Cancer 4:401-411, 2004

48. Rivoltini L, Carrabba $M$, Huber $V$, et al: Immunity to cancer: Attack and escape in T lymphocyte-tumor cell interaction. Immunol Rev 188:97-113, 2002

49. Saika T, Satoh T, Kusaka N, et al: Route of administration influences the antitumor effects of bone marrow-derived dendritic cells engineered to produce interleukin-12 in a metastatic mouse prostate cancer model. Cancer Gene Ther 11:317-324, 2004

50. Murakami T, Tokunaga N, Waku T, et al: Antitumor effect of intratumoral administration of bone marrow-derived dendritic cells transduced with wild-type p53 gene. Clin Cancer Res 10:3871-3880, 2004

51. Mazzolini G, Narvaiza I, Perez-Diez A, et al: Genetic heterogeneity in the toxicity to systemic adenoviral gene transfer of interleukin-12. Gene Ther 8:259-267, 2001
52. Philpott NJ, Nociari M, Elkon KB, et al: Adenovirus-induced maturation of dendritic cells through a PI3 kinase-mediated TNF-alpha induction pathway. Proc Natl Acad Sci U S A 101:6200-6205, 2004

53. Morelli AE, Larregina AT, Ganster RW, et al: Recombinant adenovirus induces maturation of dendritic cells via an NF-kappaBdependent pathway. J Virol 74:9617-9628, 2000

54. Diehl S, Anguita J, Hoffmeyer A, et al: Inhibition of Th1 differentiation by IL-6 is mediated by SOCS1. Immunity 13:805-815, 2000

55. Borg C, Abdelali J, Laderach D, et al: NK cell activation by dendritic cells (DC) require the formation of a synapse leading to IL12 polarization in DC. Blood 104:3267-3275, 2004

56. MacPherson G, Kushnir N, Wykes $M$ : Dendritic cells, $B$ cells and the regulation of antibody synthesis. Immunol Rev 172:325-334, 1999

57. Kim KW, Kim SH, Shin JG, et al: Direct injection of immature dendritic cells into irradiated tumor induces efficient antitumor immunity. Int J Cancer 109:685-690, 2004

58. Shimizu K, Fields RC, Giedlin $M$, et al: Systemic administration of interleukin 2 enhances the therapeutic efficacy of dendritic cell-based tumor vaccines. Proc Natl Acad Sci U S A 96:2268-2273, 1999

59. Murillo O, Arina A, Tirapu I, et al: Potentiation of therapeutic immune responses against malignancies with monoclonal antibodies. Clin Cancer Res 9:5454-5464, 2003

60. Hodi FS, Mihm MC, Soiffer RJ, et al: Biologic activity of cytotoxic $T$ lymphocyteassociated antigen 4 antibody blockade in previously vaccinated metastatic melanoma and ovarian carcinoma patients. Proc Natl Acad Sci U S A 100:4712-4717, 2003 